\title{
Urgency of Information and Technology Systems to Pass the National Character Value in Oral Literature
}

\author{
Silvia Rosa ${ }^{1}$, Hasanuddin ${ }^{2}$ \\ 1,2 Faculty of Humanities, Andalas University, Padang, Indonesia \\ *silviarosa@hum.unand.ac.id
}

\begin{abstract}
This article discusses the function of literature in shaping human character. The values mandated in literary works, especially folklore have a strategic role in shaping and perfecting behavior. They are very useful in guiding people's attitudes and mindsets as literary readers and lovers, especially folklore from West Sumatra. Humans can use information systems and technology to carry on important values in folklore. But the extent to which progress has been used to pass down the values of the character's formation. It turns out that discussion in that direction has not yet been conducted. There are three folktales from West Sumatra, which are the focus of the analysis in this article. All three are sourced from folklore that is still alive and developing in communities in West Sumatra, namely "Bujang Lenguang Bujang Pemburu", "Rawa Manisan", and "Kuduak Batu Jawi. This study uses functional research methods to dismantle the values of character education that are useful for the development of national character, especially for mental knowledge and the simplicity of young people in West Sumatra. Thought to offer the use of information systems and technological advances were raised based on the crucial function of literary works in shaping the nation's character. Research shows that literature has a role as an aesthetic teaching tool and is veiled. Folklore is a means to convey teachings about the value of politeness for readers or connoisseurs of literature. Literature must play an essential role in shaping the character of the Indonesian nation in the future. Advances in information systems and technology can help in carrying out and carrying out these literary functions.
\end{abstract}

Keywords: Literature; Values; National Character; Information System and Technology

\section{Introduction}

Literature comes from the essential words "sas" and the suffix "tra" which comes from Sanskrit. The root word "sas" means to direct, teach, give instructions or teach. Instead "tra" means disguised, secret [1]. Thus, etymologically the word literary means as a tool or way to teach, giving guidance that takes place in secret. The term "literature" in Indonesian is often given at the beginning and end so that it becomes literary, meaningful as a collection of beautiful writings that can provide teachings and instructions for readers that take place in disguised ways. Literary works using beautiful sentences by maximizing the use of style, and of course, will be rich in meaning. Literary works are not only written texts but also delivered orally.

One form of oral literary works is folklore. Folklore is abundant wealth and a treasure of Indonesian literature. Each tribe in Indonesia has a variety of distinctive folktale, containing 
precious teaching values and useful for the formation of national character. One of the tribes that are rich in various folklore is the Minangkabau in the province of West Sumatra. The three folktales discussed in this paper is entitled "Bujang Lenguang Bujang Pemburu" (a boy who was cursed to become a stone like a hunter); "Rawa Manisan" (a girl who was cursed to sink into a large swamp filled with water) and "Kuduak Batu Jawi" (a cowherd boy who was cursed into stone resembling the nape of a cow).

Folklore, as a form of literary work in its capacity as an imaginative and aesthetic work, is a means to express what can not be vulgarly shown by human reason. There are many associations and connotations in literary texts (folklore) that contain unspeakable meaning in everyday language. Literature (folklore) presents a synthesis of things that are contradictory as well as various contradictions between phenomena that are realized and not realized [2]. Through literature, we can imagine the reality that underlies the process of creation. Social reality is material from literary works. Thus it can be said that a literary work consists of social facts and literary facts. Social fact imagine the social structure of society, while literary fact implies a literary structure as a work of aesthetic and imaginative creation, which at the same time means the writer's value and thought in looking at social structure.

Some peoples states that social structure is a pattern of relationships between people and between groups of people. Social structure is also defined as a concept that forms a pattern of coating and relationships between people who are bound in a social system that is controlled by norms and also mutually agreed to behaviour patterns [3]; [4]; [5]. Brown stated the concept of function is related to the contribution made by partial activity to the overall operation, which is the parent of partial exercise [6]. Brown further explained that the contribution relates to the level of need for conditions essential to the overall social existence that must be met by an activity. This condition marks social integration in two situations, namely: a) the need for a social system that can mark structural consistency; b) the need for a social network that can express continuity so that interactions can run smoothly and regularly.

The social structure of society controls the actions of individuals in the community [7]. Be behind a real relationship. The social structure can be the background for the dives of all people's lives. Literary works record the social construction of society which is the background of its creation. Literary works can represent the entire life of the people who are the background of their production. Folklore is one of them from the genre of prose literature. How do we use the progress of information systems and technology to convey the values of character education stored in literary works, especially folklore? This paper tries to stimulate thinking in that direction.

\section{Methodology}

The research data was collected by using the method and technique of folktale research. The object of folktale research is divided into three parts, namely oral, half oral, and nonverbal folktale. The data of this study are included in the first type, namely oral folklor. There are several categories that belong to the type of oral folklor. One of the most important of them is the folktale, as the object of this research. Three folktales that became the focus of this study were collected through audio recording techniques from informants who were determined in the field. The folktale titled "Bujang Lenguang Bujang Pemburu" and "Rawa Manisan" developed in the middle of Lipek Pageh villagers, district of Lembah Gumanti, Solok district. The story titled "Kuduak Batu Jawi" was obtained from the village of Batu 
Bagiriak, Alahan Panjang, Solok district. The three stories were recorded from the informants that had been determined.

The results of audio data recording resumed at the stage of transcription and transliteration. Data transliteration results are analyzed by observing aspects of the content value and functions carried by these three folktale. The three folktale referred to in this discussion comes from Minangkabau. Each story of the transliteration result is written on one data archive card as commonly done in documentation of folktale data. Each story of the transliteration result is written on one data archive card as commonly done in documentation of folktale data. After that done the analysis of the story content to explore the values and meanings contained in the literature, as well as the functions carried by the literature in relation to the society supporting the literature (folktale).

\section{Result and Discussion}

The first story entitled "Bujang Lenguang Bujang Pemburu" is about a boy who was raised by a simple parent living in a forest. The simplicity of his parents' lifestyle was because his parents were only a farmer. In fact, before becoming a farmer, the father worked as a deer hunter into the forest. However, ever since he was attacked by a deer, he stopped being a hunter. His wife was just a rice mason from house to house. They have a son who has been longing for their presence. The boy is named Bujang.

The Bujang grew up with enough affection from both parents, despite the economic life of their households in need. In fact, the Bajang seemed to be pampered by Mom. Indulgence is none other than the Bujang is the only child of the two puppets. The parenting pattern that spoiled the Bujang, apparently has a bad effect on the behavior of the Bujang. The bachelor grows into a child who likes to impose the will on his mother. One day the Bujang tricked his mother to fulfill his desire to go to the forest following the group of deer hunters. Though the mother never allowed the Bujang to go to the forest. The bachelor managed to fool his mother who was away to work. The Bujang's success deceived his mother the first time, making the Bujang perform the same action the next time. However, on this second time the Bujang asked to make rice wrapped to his mother. The bachelor can not wait for the mother who is performing the prayer. He shouted for the mother to prepare the rice wrap for her lunch to go hunting forests. The bachelor can not wait for his mother to finish praying. Suddenly the Bujang pushed his mother's body down to the floor. After pushing her mother down, the Bujang went straight to the forest. The bachelor does not care about his mother who is in pain from falling. The bachelor walks toward the forest holding a pole and a dog to hunt. After a long walk into the forest, the Bajang was hungry. He began to be anxious because he did not bring rice packs from home. The Bajang rested while sitting pensively. While hungry in the midst of the forest, suddenly the Bajang felt his head dizzy and saw his body turned into a large rock that looks like a human. Dogs and poles carried by the Bujang also turned into stone.

The second story, entitled "Rawa Manisan" tells the story of a mother who has a daughter who is still in junior high school. His daughter is called the Gadih. The Gadih is often embarrassed to have a poor mother and work as a dishwasher at a neighbor's house in their village. One day the Gadih and his mother were invited to go to a wedding ceremony at the home of an acquaintance in the next village. The Gadih goes with his mother. The two men came up with a very contrasting makeup. The mother is wearing a very simple dress, the quiz 
of the Gadih wearing a nice dress and stylish. The mother is dressed simply because in the house of the partying person, the mother will work as a dirty dishwasher. The mother will get the wages of the work he does. While the Gadih came to the party only to meet with friends and people next door who invited him.

After a day at the house of the party, Gadih invited his mother to go home. The invitation of the Gadih is not directly obeyed by her mother because the dishwashing job is not finished yet. The Gadih was immediately angry and cursed his mother in front of the crowd. Not long ago, the mother rushed home with the Gadih. However, in the middle of the journey to go to their village, there was a tragic and extraordinary events. Suddenly a very heavy rain. Mother and daughter had one umbrella. Under the heavy rain that accompanied their journey home, suddenly the Gadih plunged into the waterlogged marshes. The Gadih tries to call his mother for help. However, the mother did not listen to the cry for help from the Gadih. Perhaps the mother was upset over the treatment of the Gadih who had cursed herself in the house of the partying person. Her mother kept walking hurrying toward their village, while the Gadih was lagging far behind her mother. The Gadih called out to his mother in the sound of the rain. However, her mother did not listen to her daughter's call. Finally, the Gadih sank into the swamp filled with puddles. Since then the Gadih has been swallowed by the earth because it plunges into swamps that are inundated by rain.

The third story is titled "Kuduak Batu Jawi". This story is about a boy whose job is to feed a cow. The boy named Buyuang. His daily work is tending cattle in the fields. One day, Buyuang felt tired when he was tending cattle. It was a hot day. Therefore Buyuang rested in a hut located in the middle of rice fields. Apparently, he fell asleep because of the wind that blows in the middle of the rice fields. Unwittingly, he herds cattle looking for grass into other people's fields. Unfortunately, the cow has damaged and searched the rice fields in people's fields. Spontaneously, the rice field owner became angry and condemned Buyuang for not tending cattle properly. The owner of the cow is Etek Baniah. He shouted at Buyuang who was sleeping in the hut. Instantly the Buyuang woke up from his sleep. Buyuang was afraid of being scolded by Baniah Ethics. Although Buyuang has apologized for his negligence, Baniah Etek does not want to forgive Buyuang. In fact, Buyuang was required to pay damage to the Etek Baniah rice field for three million rupiah. Of course Buyuang was frightened because he knew his parents would not be able to pay compensation like that.

Suddenly, Buyuang's parents came to the fields. Automatically, Etek Baniah submitted a request for compensation to Buyuang's parents. Buyuang's parents tried to apologize to Etek Baniah for the mistakes made by his son. Both parents promised to fulfill the demands of the Baniah ethic. They returned to his cabin. While Buyuang went herding the cow to another place. A few moments later, the day began to dusk. Buyuang will go home. Actually, he was afraid to go home. He thought his father would scold him. However, Buyuang still tried to strengthen his heart to go home, even though he was very afraid of his father's anger.

After arriving home, Buyuang's parents asked for a more detailed explanation of what happened in the Etek Baniah rice field this afternoon. Buyung is not polite to answer the questions of his parents. Buyuang expressed his disappointment at his parents while saying harsh words. He felt sorry that he had been born to a poor mother and an unemployed father. He was also sad because he could never go to school. His father and mother were unable to send him to school. Buyuang exploded his disappointment while delivering a statement as contained in the following data quote:

"I would rather be a stone child than a child of. I truly regret being born and raised by a poor mother and an unemployed father!".

(Results of data translation by Silvia Rosa, 2018). 
The boy shouted at father and mother. The poverty factor experienced by parents caused Buyung not to be able to go to school, so he did not have friends to play in his village. Children his age mostly play while Buyung has no friends because every day, his job is tending cattle. Buyuang was upset and angry with his parents. The father became furious at the words of his son who cursed his parents. Spontaneously, the father becomes emotional and responds to his child's requirements with anger as well. Fathers also say angry words to boys as contained in the following data excerpt:

"You ungodly child. If you don't like being my child, be a stone child!". The father cursed his son while angry.

(Results of data translation by Silvia Rosa, 2018).

After hearing his father's words, Si Buyuang ran fast into the forest while dragging his shepherd cow. He did not come home until the evening. In fact, Buyuang hasn't been home for two nights. Both parents begin to worry and worry. His parents searched the rice fields in the village where his son often tended cattle. However, his son did not meet. Suddenly, Buyuang's parents got the news that in the forest a large stone was found and was very similar to the nape of a cow. The front of the stone is shaped like a cow's neck at a glance similar to Buyuang's face. The father was sorry in his heart when he heard the story of the villagers. The curse words that had been issued by Buyuang's father were granted by God. Si Buyuang was transformed into a large stone that resembled the nape of a cow. The father of Buyuang regretted cursing his own son. But regret is useless.

The three folklore of West Sumatra wants to pass down essential values in character education. We believe that through this folklore, the community seeks to educate children and also parents in caring for their children. Folklore contains messages about the ethics of speaking, both for children to older people and the ethics of speaking of parents to their children. The following table 1 shows the contents of the values stored in the three folklore after being detained based on the message content analysis. Table 1 below presents the educational messages contained in the three folklore discussed in this study.

Table 1. The educational messages in three folklore

\begin{tabular}{lllll}
\hline No & Conten & BLBP & RW & KBJ \\
\hline 1 & Don't spoil the child too much & $\sqrt{ }$ & $\sqrt{ }$ & \\
2 & $\begin{array}{l}\text { The importance of instilling the } \\
\text { value of politeness in children }\end{array}$ & $\sqrt{ }$ & $\sqrt{ }$ & $\sqrt{ }$ \\
3 & $\begin{array}{l}\text { The importance of obeying and } \\
\text { respecting parents }\end{array}$ & $\sqrt{ }$ & $\sqrt{ }$ & $\sqrt{ }$ \\
4 & $\begin{array}{l}\text { Dare to be responsible } \\
\text { The importance of saying kind }\end{array}$ & $\sqrt{ }$ & $\sqrt{ }$ & $\sqrt{ }$ \\
5 & $\begin{array}{l}\text { Words } \\
6\end{array}$ & & & $\sqrt{ }$ \\
7 & $\begin{array}{l}\text { Mutual respect for the rights of } \\
\text { others }\end{array}$ & & & \\
8 & $\begin{array}{l}\text { Be polite to parents } \\
\text { Parents must not curse their } \\
\text { children }\end{array}$ & & & $\sqrt{ }$ \\
9 & $\begin{array}{l}\text { Don't swear carelessly } \\
10\end{array}$ & Don't feel useless & & $\sqrt{ }$ \\
11 & Don't be arrogant & $\sqrt{ }$ & & $\sqrt{ }$ \\
\hline
\end{tabular}


Note:

BLBP : Bujang Lenguang Bujang Pemburu

RW : Rawa Manisan

KBJ : Kuduak Batu Jawi

This three folklore can bequeath noble values that are useful for the formation of character, both for the younger generation and for the elderly. One of the essential educational benefits is the teaching that a person must be able to speak politely to his parents. A child must be able to develop techniques that speak smooth and polite to his parents. The Minangkabau ethnic group that dominates the province of West Sumatra categorizes the ethics of speaking in society in four parts, commonly referred to as the Kato nan Ampek (Fourth Word). Kato nan Ampek is the four kinds of ethics of talking an individual with others. Kato nan Ampek is a norm system that regulates individuals talking with others based on ethical principles. The rules of speaking apply between individuals of the same age, with older age, an earlier age to younger ones, and also regulations of speaking to a brother-in-law. [8]; [9]; [10]; and [11]. Kato nan Ampek's philosophy is the basis for the behaviour of each individual in establishing communication with other individuals in society. Folklore can teach the art of conversation based on local wisdom [12]; [13].

Educational values contained in folklore has become a guide in the formation of attitudes and character of the society that supports folktale in his day. But over time, folklore narratives are no longer a tradition that parents usually carry out to their children today. Children today are no longer interested in listening to fairy tales. They prefer watching cartoons on television. The causative factor can come from many television programs that pamper children with a more attractive impression. Besides, parents are busy with work to meet their daily needs, so they do not have enough time to tell their children at home about folklore again. This condition also affects the alienation of children with the tradition of storytelling folklore from their area.

Factors that cause the breakup of young people with a wealth of folklore repertoire should not occur. Government interventions to reconnect young people with literary traditions must be carefully programmed because literature has the potential to develop the subtlety and politeness of the behaviour of readers and listeners. Literary works have the opportunity to reconcile the hustle and bustle of inhospitable physical disputes that harm the younger generation. Literary works can bridge the leaders with the people they lead if the same does not apply. Literary works have the opportunity to convey ideas that cannot be said transparently. Literature can express bitterness beautifully and politely.

The government and all of us can help the alienation of the younger generation from their home folklore. The program of digitizing folklore provides an opportunity to bring folktale closer to millennial children. We can make short films with the essential ingredients of folktale. We can make soap operas with the theme of the story that comes from folklore. What has been done to the myths of the North American people entitled Thunderbird[14]; also against Cinderella [15]; also about the magic that became the idea for the Harry Potter films [16]; also about Japanese folklore entitled Momotaro [17]. 


\section{Conclusion}

Conveying the value of education through folklore is a vital strategy to help the younger generation from cases of moral decadence, especially towards parents.. Even though civilization is increasingly modern, the message contained in folklore is still relevant to the times and human culture. Retelling folklore to children from an early age can be one of the nation's character building strategies. Storytelling and listening to stories are fun literary activities that are loved by many people, including children and adolescents. At the same time the delivery of ideal ethical norms in behaviour and speech can be conveyed to the listener. This activity is a real form of literary function that teaches the reader or listener in a vague and veiled way.

Imagine, if literary activities, such as the narrative of these three folklore in West Sumatra - even anywhere in the world - could still be massive in the community, both in formal forums - through teaching and learning in formal and non-formal schools, through meetings routine meetings and early childhood play, as well as thematic recreational activities with nuances of literary arts. Of course, literature will really carry out its function as an aesthetic and veiled teaching tool. This pattern has actually happened in Indonesian society in the past. However, along with the rapid and extraordinary development of information technology in recent times, fairy tale activities fade and are no longer in demand. Educational values stored in three folklore are no longer inherited continuously. The growth of the character of the younger generation began to change direction, from humans who have friendly personalities, polite, polite, sociable, have sense of culture, obey in religion, change into an individual figure, indifferent, do not have the value of courtesy, not happy with local culture, and disobedience to religion.

The function of literature in shaping the character of the nation must be able to the maximum. The progress of information and technology systems can be a means to carry out literary functions. Millennials prefer digital technology, instant entertainment, technologybased games, so it is necessary to make an effort to accommodate their enjoyment in hearing and enjoying digital-based folklore.

\section{References}

[1] A. Teeuw, Sastra dan Ilmu Sastra: Pengantar Teori Sastra, 3rd ed. Jakarta: Pustaka Jaya, 2003.

[2] J. van Luxemburg, M. Bal, and W. G. Weststeijn, Pengantar Ilmu Sastra. Jakarta: Gramedia, 1984.

[3] Q. Saleha, "Kajian Struktur Sosial dalam Masyarakat Nelayan di Pesisir kota Balikpapan (Social Structure of Fishermen Communities in Balikpapan Coastal Zone )," Bul. Psp, vol. 21, no. 1, pp. 67-75, 2013.

[4] A. Rahman, "Struktur Sosial Politik Kerajaan Loloda di Antara," Al-Turās, vol. XXI, no. 2, pp. 205-228, 2015.

[5] Y. K. Wardani, Y. Herwangi, and A. Sarwadi, "Peran Struktur Sosial dalam Pembangunan Sarana Prasarana Permukiman Perkotaan (Studi Kasus: PLPBK Kelurahan Karangwaru Kecamatan Tegalrejo Kota Yogyakarta),” J. Ilmu Pemerintah. Widya Praja, vol. 44, no. 1, pp. 1-20, 2018

[6] J. H. Turner and A. Maryanski, Fungsionalisme, 1st ed. Yogyakarta: Pustaka Pelajar, 
2010.

[7] Koentjaraningrat, Pengantar Ilmu Antropologi, 6th ed. Jakarta: Aksara Baru, 1986.

[8] W. Alti, "Pendidikan Inklusi Berbasis Nilai Kearifan Lokal di SEKOLAHALAM MINANGKABAU Kota Padang Sumatera Barat," Cult. Soc. J. Anthropol. Res., vol. 1, no. 3, pp. 172-179, 2020.

[9] L. Hadijah, "Local Wisdom in Minangkabau Cultural Tradition of Randai," KnE Soc. Sci., vol. 2019, pp. 399-411, 2019.

[10] E. Efrianto and A. Afnita, "The Politeness of Bungo Pasang Language Using Kato Nan Ampek in Minangkabau," J. KATA, vol. 3, no. 1, p. 58, 2019.

[11] Navis, Alam Takambang Jadi Guru, 2nd ed. Grafiti Press, 1986.

[12] D. Eliza, "Pengembangan Model Pembelajaran Karakter Berbasis Cerita Tradisional Minangkabau Untuk Anak Usia Dini," Pedagogik, vol. 3, pp. 153-163, 2017.

[13] S. Rosa, "TEACHING CHARACTER THROUGH ORAL STORIES IN INDONESIA AND MALAYSIA," J. Southeast Asian Stud., vol. 24, no. 2, pp. 176190, Dec. 2019.

[14] J. E. Watson, "Bald eagles and the Thunderbird myth: Birds in pre-contact ceremonialism on Martha's Vineyard, USA," Quat. Int., 2020.

[15] M. Kaplanoglou, "Spinning and Cannibalism in the Greek Cinderella: Symbolic Analogies in Folktale and Myth," Folk. (United Kingdom), vol. 127, no. 1, pp. 1-25, 2016.

[16] J. Lovell, "Fairytale authenticity: historic city tourism, Harry Potter, medievalism and the magical gaze," J. Herit. Tour., vol. 14, no. 5-6, pp. 448-465, 2019.

[17] L. K. Nüffer, "The Boy Who Came from a Peach and the Girl with a Bowl on Her Head: The Many Faces of Japanese Fairy Tales," A Companion to World Lit., no. 1947, pp. 1-12, 2019. 